\title{
Isolation of parietal cells from guinea-pig gastric mucosa and the immunological characterization of their antigenic structure
}

\author{
D. P. JEWELL ${ }^{1}$, V. N. KATIYAR, C. REES, K. B. TAYLOR, AND J. P. WRight \\ From the Division of Gastroenterology, Stanford University School of Medicine, Stanford, California
}

SUMmaRY A method is described for the isolation of parietal cells from the gastric mucosa of the guinea pig by enzymatic digestion with collagenase. A suspension was obtained that contained $70-80 \%$ parietal cells. About $80 \%$ of the cells were viable immediately after incubation, but viability dropped sharply after one hour. Parietal cells were identified by their morphology on light and electron microscopy, by their uptake of neutral red, by immunofluorescent staining and by carbonic anhydrase activity.

Antibodies to four distinct parietal-cell antigens were obtained from rabbits immunized with the isolated parietal cells or fractions thereof. These antibodies were directed against the microsomal fraction of the parietal-cell cytoplasm, the plasma and nuclear membranes, the soluble proteins, and Castle's intrinsic factor. The antibody against the microsomal fraction, though reacting in the same way as the antibody to parietal cell canaliculi found in the serum of patients with pernicious anaemia, showed greater species specificity.

Antibodies to two antigens of the gastric parietal cell are found in the sera and gastric juice of patients with pernicious anaemia. One antigen is Castle's intrinsic factor (IF), which appears to be located within the cell in a peripheral distribution (Fisher and Taylor, 1969), and the other, a water-insoluble antigen associated with microsomal fractions of the cell (Baur, Roitt, and Doniach, 1965), appears to be localized to the microvilli of the canalicular system (Hoedemaeker and Ito, 1970).

Evidence for cell-mediated immune respouses in pernicious anaemia has also been reported. Chanarin and James (1974) have shown that lymphocytes from patients with pernicious anaemia will transform in response to human gastric juice in $38 \%$ of patients tested. They also demonstrated a cellular response to human gastric juice and hog IF using the leucocyte migration inhibition test but this is in contrast to the findings of Goldstone, Calder, Barnes, and Irvine (1973) who, using the same test, could not detect any difference between pernicious anaemia and control lymphocytes in response to intrinsic factor. However, the latter authors did

'Current address: Department of Medicine, The Royal Free Hospital, Pond Street, London, NW3 2QG.

Received for publication 20 May 1975. find evidence of a cellular immune response to various gastric mucosal fractions and to liver mitochondria although the leucocytes of some control patients also showed a positive response.

The role of gastric antibodies or cell-mediated immune responses in causing or perpetuating the gastric disease process remains undefined, although they are clearly evidence of an abnormal immune response. So far, no direct evidence has been obtained to show that such antibodies are cytotoxic to parietal cells. However, results suggestive of cytotoxic damage have been obtained by some investigators. Tanaka and Glass (1970) documented a reduction of parietal-cell mass in rats repeatedly injected with parietal canalicular antibody and Inada and Glass (1972) showed a similar reduction of gastric chief cells associated with repeated injections of intrinsic factor antibody into rats (in this animal the chief cell is the source of IF). No concomitant inflammatory response, such as that described by Hausamen, Halcrow, and Taylor (1969b), was noted.The parietal-canalicular antibody has also been shown to inhibit acid production by the isolated bullfrog stomach (Hausamen, Brus, Fisher, and Taylor, 1969a).

The purpose of the present study was to isolate pure populations of gastric mucosal cells for the 
following reasons: (1) to obtain antigens defined by cell type which could subsequently be purified and characterized and used for examining both humoral and cell-mediated immune responses in pernicious anaemia and autoallergic gastritis; (2) to use such cells as target cells in studies of cytotoxicity, whether mediated by antibody or cells or a combination of the two.

\section{Materials and Methods}

\section{ANIMALS}

Parietal cells were isolated from the stomachs of Hartley strain guinea pigs weighing 300-600 g. Rabbits were used for all immunizations.

\section{SERA}

Sera were collected from patients with pernicious anaemia and chronic atrophic gastritis, and stored at $-20^{\circ} \mathrm{C}$.

\section{ISOLATION OF PARIETAL CELLS}

\section{Perfusion method}

Perfusion of the stomach was adapted from the procedure described by Berry and Friend (1969) for the isolation of liver cells. Guinea pigs were anaesthetized with intraperitoneal Nembutal. The arterial supply to the stomach was perfused with Hanks' solution (Grand Island Biological Company) until most of the blood had been flushed out. Perfusion was then continued for $10,20,40$ or 60 min with Hanks' solution containing $0.05 \%$ collagenase (Sigma, type I) at a rate of 2 to $3 \mathrm{ml}$ per minute. The Hanks' solution was gassed continuously with 95\% oxygen and 5\% carbon dioxide. Following perfusion, the stomach was removed, washed with $0.9 \%$ saline, and the mucosa scraped off with a glass slide. The mucosal fragments were put through a stainless steel grid (60 gauge) and suspended in medium 199 (GIBCO). They were gently shaken for four to five min and then centrifuged at $10 \times g$ for five minutes. All these procedures were performed at $4^{\circ} \mathrm{C}$. The supernatant was examined for cells using phase-contrast microscopy. This perfusion method did not separate the cells from the gastric mucosa. Therefore we attempted incubation of the mucosa with collagenase.

\section{Incubation in vitro}

Guinea pigs were stunned and their stomachs removed, opened and rinsed with $0.9 \%$ saline to remove contents. As much mucus as possible was removed by gentle wiping with a paper tissue. The antrum was cut off and the mucosa of the body of the stomach was removed from the muscularis mucosae by scraping with a glass slide. The scrapings were pressed through a stainless steel grid (60 gauge) and suspended in medium 199. These procedures were performed at $4^{\circ} \mathrm{C}$. The mucosal fragments were allowed to settle for five to $10 \mathrm{~min}$, and the supernatant was poured off. Two to three $\mathrm{ml}$ of fragments was added to $5 \mathrm{ml}$ aliquots of medium 199 in $25 \mathrm{ml}$ conical flasks. Collagenase (Sigma, type I) was added to give a concentration of $0.05 \%$. The flasks were incubated at $37^{\circ} \mathrm{C}$ with gentle shaking and were gassed continuously with $95 \% \mathrm{O}_{2}$ and $5 \% \mathrm{CO}_{2}$. After $20 \mathrm{~min}$, the contents of each flask were centrifuged at $10 \times g$ for five min at $4^{\circ} \mathrm{C}$ and the supernatant was carefully removed. The pellet was re-incubated in $5 \mathrm{ml}$ of medium 199 containing $0.05 \%$ collagenase for a further 20 minutes. The supernatant was re-spun at $100 \times g$ for five min to bring down the isolated parietal cells. The cells were washed in Hanks' solution and were finally resuspended in medium 199. They were kept at $4^{\circ} \mathrm{C}$. Cells were harvested in this way after each 20 min incubation period until the largest possible number of cells had been obtained. The cells were finally pooled, washed in Hanks' solution, and re-suspended in 1-2 $\mathrm{ml}$ of medium 199. They were counted in a haemocytometer using phase-contrast microscopy.

\section{VIABILITY}

The viability of the isolated cells was assessed by their ability to exclude trypan blue $(0.05 \%$ in phosphate-buffered saline, $\mathrm{pH} 7.2$ ) and $0.05 \%$ lissamine green V (George T. Gurr, London). The activity of succinic dehydrogenase was assayed by staining with nitro-blue-tetrazolium (NBT) using a modification of the method of Nachlas, Tsou, de Souza, Cheng, and Seligman (1957).

\section{IDENTIFICATION}

Parietal cells were identified by: (1) their large size on phase-contrast microscopy; (2) their ability to take up neutral red $(0.1 \%)$ (Bradford and Davies, 1950); (3) immunofluorescence using smears of isolated cells made on albumin-coated slides; (4) appearances by electron microscopy. For electron microscopy, cells were fixed overnight in $1 \%$ osmium tetroxide in Millonig's phosphate buffer, $\mathrm{pH} 7 \cdot 2$, at $4^{\circ} \mathrm{C}$. They were then dehydrated in graded alcohols and embedded in Epon-araldite plastic. Sections were viewed in a JEM-100B electron microscope.

\section{ENZYME ACTIVITIES}

Carbonic anhydrase and pepsin activities were measured in the isolated, parietal-cell preparations and in the mucosal fragments from which they had been isolated. The cells and the mucosa were 
homogenized using a Potter-Elvehjem tissue grinder. The carbonic anhydrase was measured using the method of Karler and Woodbury (1963), and the pepsin was assayed using haemoglobin as a substrate (Anson, 1938). The protein content was measured by the method of Lowry, Rosebrough, Farr, and Randall (1951) and the enzyme activity was expressed as units per milligram of protein. Enzyme assays were performed in duplicate.

\section{PREPARATION OF ANTIGENS}

Homogenized parietal cells were prepared by suspending the isolated cells in $5 \mathrm{ml}$ of $\mathrm{TKM}^{1}$ and homogenizing them using a Polytron PT10 homogenizer. The homogenate was dialysed against $0.01 \mathrm{M}$ phosphate buffer $\mathrm{pH} 7.2$ containing $0.15 \mathrm{M}$ $\mathrm{NaCl}$ (PBS) and concentrated to 1-2 ml by ultrafiltration (Amicon, Model 12 with a PM10 membrane).

Cell membranes were obtained by freezing the isolated parietal cells in liquid nitrogen, then thawing in warm water; the freezing and thawing were repeated three times. The suspension of ruptured cells was centrifuged at $750 \times g$ for 10 min at $4^{\circ} \mathrm{C}$. The pellet containing the membranes was resuspended in phosphate-buffered saline.

Fractions of membranes and microsomes from the gastric mucosa of the guinea pig were prepared from a suspension of mucosal scrapings that had not been treated with enzyme. The suspension in TKM was homogenized for one to two minutes in a Polytron PT 10 homogenizer and then centrifuged at $15000 \times g$ for 15 minutes. The pellet, containing membranes and mitochondria, will be referred to as the ' $15000 \times g$ fraction'. The supernatant was centrifuged at $105000 \times g$ for one hour. This pellet will be referred to as the 'microsomal fraction'. Both pellets were washed once in PBS, re-centrifuged and then lyophilized. They were stored at $-20^{\circ} \mathrm{C}$. The supernatant from the $105000 \times g$ centrifugation contained the soluble protein. This was dialysed against PBS, concentrated by ultrafiltration and lyophilized for storage. Soluble protein was obtained from the body of the guinea-pig stomach, the antrum and the isolated parietal cells.

The microsomal fraction of the body of the hog stomach was obtained by the method of Baur et al (1965). The guinea-pig antral homogenate used to absorb antisera for immunofluorescent studies was prepared by scraping off the antral mucosa from guinea-pig stomachs. The antral mucosal fragments, suspended in TKM, were homogenized, dialysed against PBS, and then lyophilized.

$150 \mathrm{mM}$ Tris- $\mathrm{HCl}$ (pH 7.6), $25 \mathrm{mM} \mathrm{KCl}, 10 \mathrm{mM} \mathrm{MgCl} 20.25 \mathrm{M}$ sucrose
IMMUNIZATION SCHEDULES

Rabbits were immunized with: (1) whole parietal cells; (2) homogenized cells; (3) the cell membrane fraction; and (4) soluble protein from the body of the guinea-pig stomach. Approximately $10^{7}$ cells were used for each injection. One $\mathrm{ml}$ of cells, or cell fractions, was emulsified in $1 \mathrm{ml}$ of complete Freund's adjuvant (Difco) and injected intradermally at multiple sites. Three weeks later, an intravenous injection of the antigen was given. The rabbit was bled 10-14 days after the second injection. Subsequent booster injections were given intravenously as required. The antisera were stored at $-20^{\circ} \mathrm{C}$.

\section{IMMUNOFLUORESCENCE}

Gastric tissue was obtained from guinea pig, rat, rabbit, mouse, bullfrog (Rana catesbiana) and human. The tissue was immediately frozen on dry ice and stored at $-20^{\circ} \mathrm{C}$ until used. Fluoresceinated goat antisera to rabbit serum globulins and rabbit antisera to human serum globulins were obtained from Antibodies Incorporated (Davis, California). The fluoresceinated antisera were used in the proportion of $2: 1$ with rhodamine-conjugated bovine serum albumin(Microbiological Associates, Bethesda Md.). The immunofluorescent test was carried out as described by Fisher and Taylor (1965). Serum from a patient with pernicious anaemia which contained a strongly positive canalicular antibody and normal rabbit serum was included in each test as positive and negative controls. The results were read using a Zeiss Standard R.A. fluorescent microscope with Zeiss BG3 and UG5 excitor filters and a Zeiss barrier filter 50. Kodak high-speed Ektachrome was used for photography.

\section{COMPLEMENT FIXATION}

The titre of complement-fixing antibodies was determined by a micro-modification of the method of Donnelley (1951) using disposable U-plates (Cooke Engineering Co, Alexandria, Va.). Two minimum haemolytic doses of guinea-pig complement were used and the titre was expressed as the highest dilution of the antiserum which gave complete fixation of the complement. The antisera were tested at least twice.

INTRINSIC FACTOR ANTIBODIES

Sera were tested for intrinsic factor antibodies by two methods. In the charcoal assay of Gottlieb, Lau, Wasserman, and Herbert (1965), human and guinea-pig gastric juice was used as sources of intrinsic factor. ${ }^{57} \mathrm{Co}$-labelled vitamin $\mathrm{B}_{12}$ (Amersham-Searle Corp, specific activity $10 \mathrm{ci} / \mathrm{ml}$ ) was diluted with non-radioactive $B_{12}$ so that the final 
concentration of $\mathrm{B}_{12}$ was $20 \mathrm{ng} \mathrm{B}_{12}$ per $\mathrm{ml}$ and approximately $0.04 \mu \mathrm{Ci} / \mathrm{ml}$. The results were expressed as percentage inhibition by antiserum of binding between ${ }^{57} \mathrm{CoB}_{12}$ and intrinsic factor. The antisera were also tested using the guinea-pig mucosal homogenate assay (Ashworth, England, Fisher, and Taylor, 1967) which measures uptake of ${ }^{57} \mathrm{CoB}_{12}$ by homogenized intestinal mucosa in the presence and absence of antibody. In this test human gastric juice was the source of intrinsic factor.

\section{IMMUNOELECTROPHORESIS AND}

IMMUNODIFFUSION

Immunoelectrophoresis and immunodiffusion were performed on microslides layered with $1.5 \%$ Noble agar (Difco). For immunoelectrophoresis the agar was dissolved in a solution of $75 \%$ water and $25 \%$ Tris barbital sodium buffer (ionic strength 0.66 , $\mathrm{pH} 8.8$ ). Electrophoresis was run for $120 \mathrm{~min}$ with a current of $5 \mathrm{ma}$. across each frame containing six slides. Antiserum was placed in the central trough and allowed to diffuse for 18 hours.

\section{Results}

PREPARATION OF PARIETAL CELLS

Successful preparations of isolated parietal cells were obtained only when gastric mucosa was incubated with collagenase in vitro. The perfusion method adapted from the procedure used by Berry and Friend (1969) to isolate liver cells did not separate parietal cells from the gastric mucosa. Perfusions were performed using $0 \cdot 1 \%$ hyaluronidase (Sigma) as well as collagenase. The duration of perfusion was varied, but the final suspension of cells in each case contained only a few parietal cells.

Incubation of the gastric mucosa with collagenase in vitro gave cell preparations containing $70-80 \%$ parietal cells. The optimum concentration of collagenase proved to be $0.05 \%$; higher concentrations were less effective. Other enzymes (pronase, trypsin, ficin, and hyaluronidase) gave poor results. The choice of medium appeared to be critical. The best separations were obtained using medium 199 (GIBCO). Cell preparations were unsatisfactory when PBS ( $\mathrm{pH} 7 \cdot 4,0.01 \mathrm{M}$ phosphate, $0.15 \mathrm{M} \mathrm{NaCl}$ ), balanced salt solution (MacDougal and DeCosse, 1970), Hanks' solutions (GIBCO), or minimum essential medium (Eagle, GIBCO) with or without calcium was the incubation medium. Finally, stomachs from young animals were found to yield more cells than those of older animals.

The suspension of cells consisted of parietal cells singly or in clumps of three or four. Some mucus was invariably present. Small numbers of epithelial cells, chief cells, and mucous neck cells were identified by electron microscopy. A single guinea-pig stomach yielded 1.0-5.0 $\times 10^{6}$ parietal cells. Centrifugation of the suspensions on albumin or Ficoll (Pharmacia) gradients did not increase the purity of the cell suspension and considerably impaired viability.

\section{IDENTIFICATION}

The cells were readily identified as parietal cells by phase-contrast microscopy because of their large size (14-16 $\mu$ ) and their ability to take up neutral red, which is not taken up by other gastric cells. Parietal cells stained deep blue after incubation with NBT on account of their high level of succinic dehydrogenase. Epithelial cells, with a lower level of this enzyme, were faintly pink, and other cells showed no colour at all. In each of these tests, isolated cells were compared with intact glands and frozen tissue sections stained in the same way.

Electron micrographs showed the characteristic parietal-cell canaliculi lined with microvilli and cytoplasm packed with numerous mitochondria (fig 1). Identification was further confirmed by immunofluorescence. Smears of the isolated parietal cells were incubated with serum of a patient with pernicious anaemia known to contain antibodies to gastric parietal cells, followed by fluoresceinated rabbit antiserum to human globulins. The isolated cells fluoresced under uv light (fig 2). Similar smears of epithelial cells could not be stained this way. The rabbit antisera to the isolated cells were absorbed with a lyophilized homogenate of guinea-pig antrum to remove any antibodies directed against mucus, connective tissue, chief cells, epithelial cells, or mucous neck cells. Smears of the isolated cells were incubated with the absorbed rabbit antisera followed by fluoresceinated antiserum to rabbit immunoglobulins, and again only parietal cells fluoresced (fig 3).

In our experiments the simplest and most accurate estimate of purity was obtained by direct count under the phase-contrast microscope of cells that took up neutral red. BreMiller (1961) used estimations of carbonic anhydrase and pepsin activities as a criterion of separation of parietal cells from other cells of the gastric mucosa. Our own data show an increase of carbonic anhydrase activity (expressed as units of enzyme activity per milligram of protein) compared with the activity in the whole mucosa and a fall in pepsin activity (table III).

\section{VIAB ILITY}

The cells obtained after incubation for 90 to $120 \mathrm{~min}$ with collagenase were usually viable. More than $80 \%$ excluded trypan blue and lissamine green. 


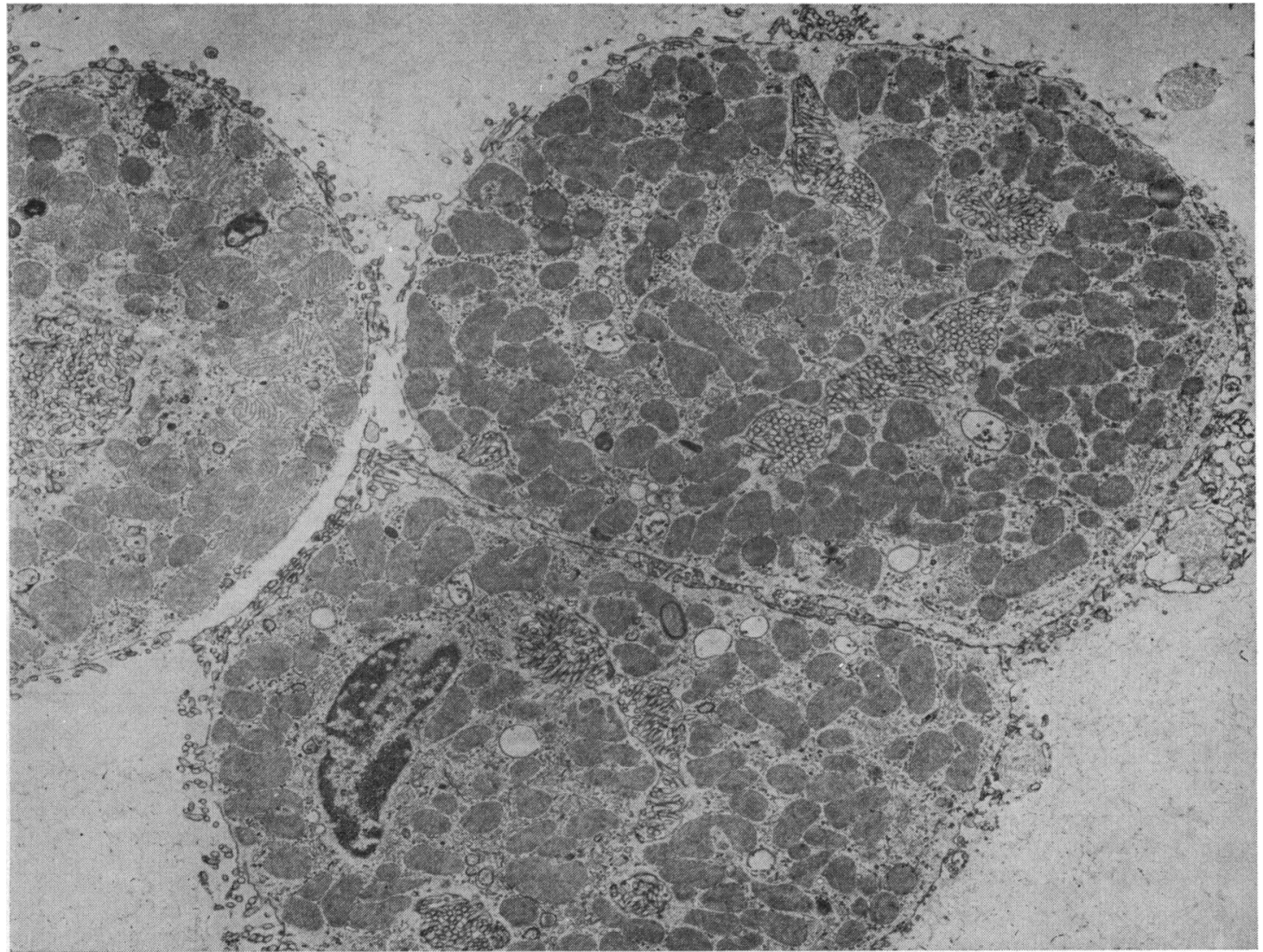

Fig 1 Electron micrograph of isolated parietal cells

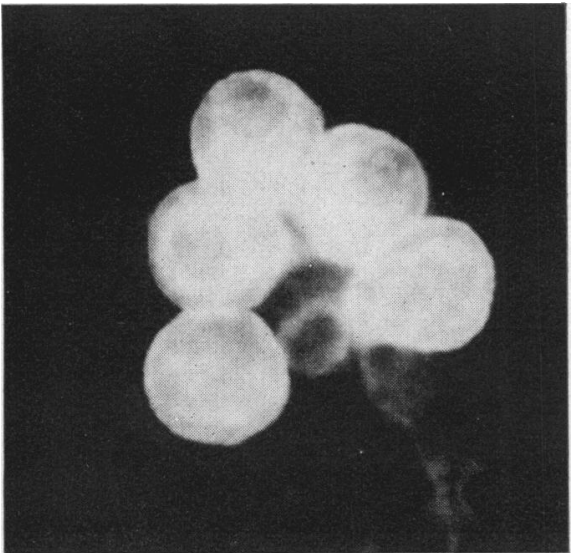

Fig 2 Isolated parietal cells stained with serum from a patient with pernicious anaemia and fuorescein-conjugated antihuman globulin.

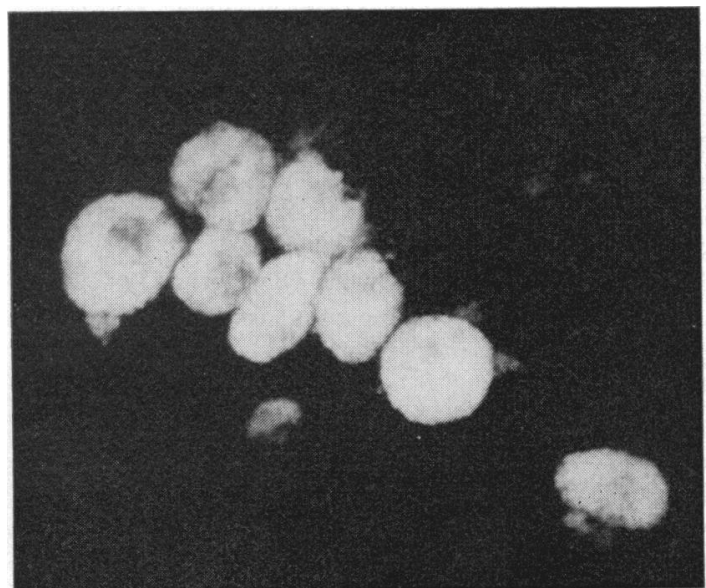

Fig 3 Isolated parietal cells stained with a rabbit antiserum to isolated whole parietal cells and a fuorescein-conjugated antirabbit globulin. 


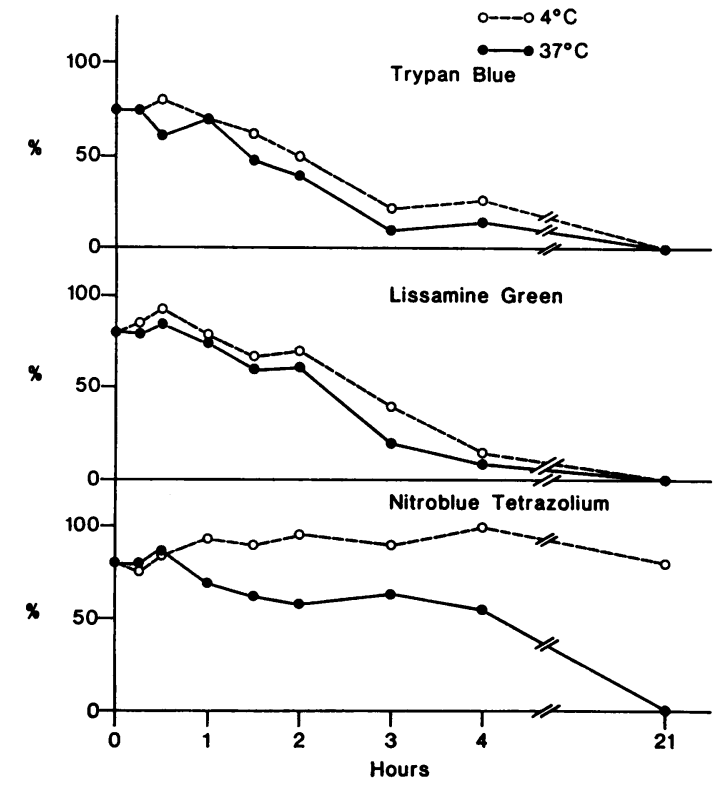

Fig 4 Percentage of isolated parietal cells which excluded trypan blue and lissamine green and which stained with nitro-blue-tetrazolium. The time course represents hours following isolation.

Further experiments were performed to examine the viability of the isolated cells. Cells were incubated at 37 and $4{ }^{\circ} \mathrm{C}$ in medium 199 oxygenated with $95 \% \mathrm{O}_{2}-5 \% \mathrm{CO}_{2}$. Aliquots were taken at intervals and the percentages of cells excluding trypan blue or lissamine green were determined. Mean percentage viabilities by the dye exclusion tests are shown in figure 4. Approximately $75 \%$ of the cells were alive one hour after the termination of enzymatic treatment and $50 \%$ at two hours. The differences in survival at 30 and $4^{\circ} \mathrm{C}$ were not significant. Viability was not improved when the incubation medium was supplemented with $10 \%$ fetal-calf serum (GIBCO). Succinic dehydrogenase activity, as measured by the NBT method, persisted for a much longer time. Cells kept at $4^{\circ} \mathrm{C}$ regularly showed activity at 21 hours (fig 4) although at $37^{\circ} \mathrm{C}$ there was no demonstrable staining at this time.

The appearance of the cells in electron micrographs supported the conclusions drawn from the dye exclusion tests. A large proportion of the cells appeared to be in good condition, mitochondria were not swollen, and cell organelles appeared intact. The plasma membranes, however, did not always appear to be continuous, probably because damage occurred in the separation or processing.

PRODUCTION OF ANTIBODIES

Antibodies against four distinct components of the parietal cell were detected by a number of tech- niques. The three antisera to preparations of isolated parietal cells all contained antibodies to guinea-pig parietal cells when tested by indirect immunofluorescence. These antisera also contained antibodies to other elements of the gastric mucosa, which were absorbed with a lyophilized homogenate of guinea-pig antrum.

An antibody which produced cytoplasmic staining of the parietal cells was found in each of the antisera (fig 5). The antibody was specific for the gastric parietal-cell cytoplasm; no fluorescence was detected when the antisera, absorbed with antrum, were tested on frozen sections of guinea-pig kidney, liver, or small intestine. The rabbit antibody to parietalcell cytoplasm resembled the antibody to the parietal-cell canaliculus found in serum from patients with pernicious anaemia in that both could be absorbed with hog-stomach microsomes. The rabbit antibody, however, cross-reacted with gastric

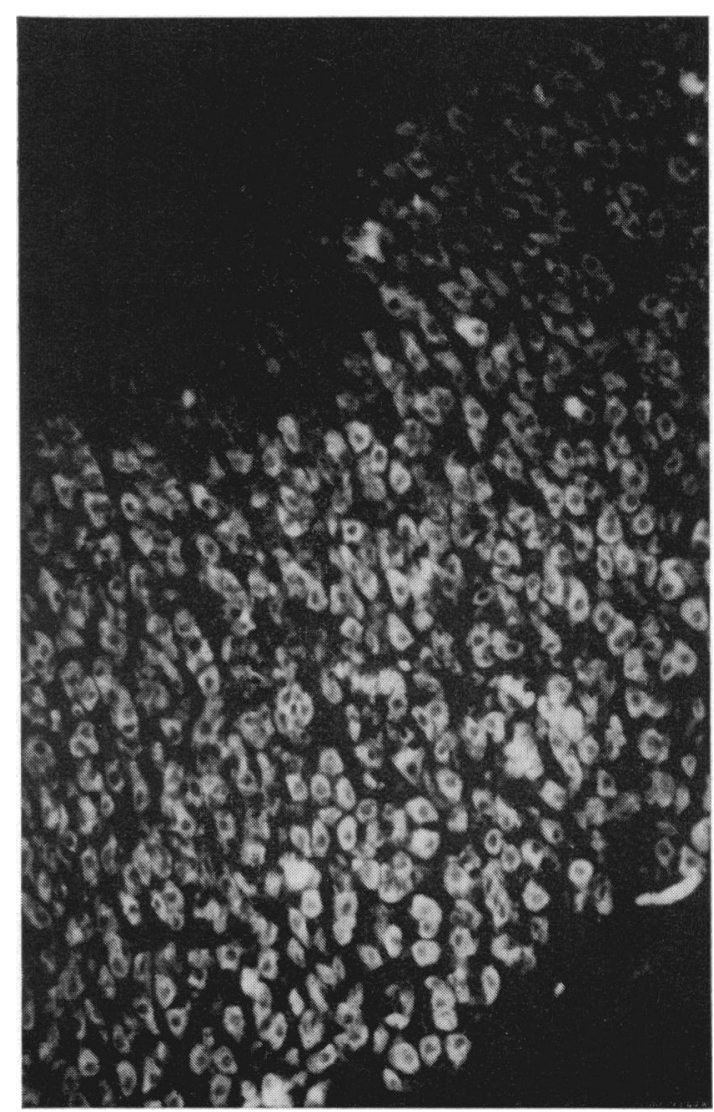

Fig 5 Guinea-pig gastric mucosa stained with the antiserum to the membrane fraction of isolated parietal cells and a fluorescein-conjugated antirabbit globulin The antiserum had been absorbed with antral homogenate. 


\begin{tabular}{|c|c|c|c|c|c|c|}
\hline Antiserum ${ }^{2}$ & Guinea Pig & Human & Rat & Rabbit & Mouse & Frog \\
\hline $\begin{array}{l}\text { Antiwhole parietal cell } \\
\text { Absorbed with microsomes }\end{array}$ & $\begin{array}{l}+++ \\
-\end{array}$ & $\begin{array}{l}+ \\
-\end{array}$ & + & + & + & $\begin{array}{l}+ \\
+\end{array}$ \\
\hline $\begin{array}{l}\text { Antihomogenized cells } \\
\text { Absorbed with microsomes }\end{array}$ & $\begin{array}{l}++ \\
-\end{array}$ & + & + & \pm & \pm & + \\
\hline $\begin{array}{l}\text { Anticell membrane } \\
\text { Absorbed with microsomes }\end{array}$ & $\begin{array}{l}++t \\
+\end{array}$ & $\begin{array}{l}+ \\
-\end{array}$ & $\overline{-}$ & + & + & $\begin{array}{l}+ \\
\pm\end{array}$ \\
\hline $\begin{array}{l}\text { Pernicious anaemia serum } \\
\text { Absorbed with microsomes }\end{array}$ & $\frac{++}{-}$ & $\begin{array}{l}++ \\
-\end{array}$ & $+t+$ & $\begin{array}{l}++ \\
-\end{array}$ & $\begin{array}{l}++ \\
-\end{array}$ & $\begin{array}{l}+++(12 / 17 \text { sera }) \\
-\end{array}$ \\
\hline
\end{tabular}

Table I Results of immunofuorescent studies to demonstrate cross-reactivity between antibodies to guinea pig parietal cells and the parietal cells of other species

${ }^{1}$ All absorbed with guinea pig antral mucosa

'From hog gastric mucosa

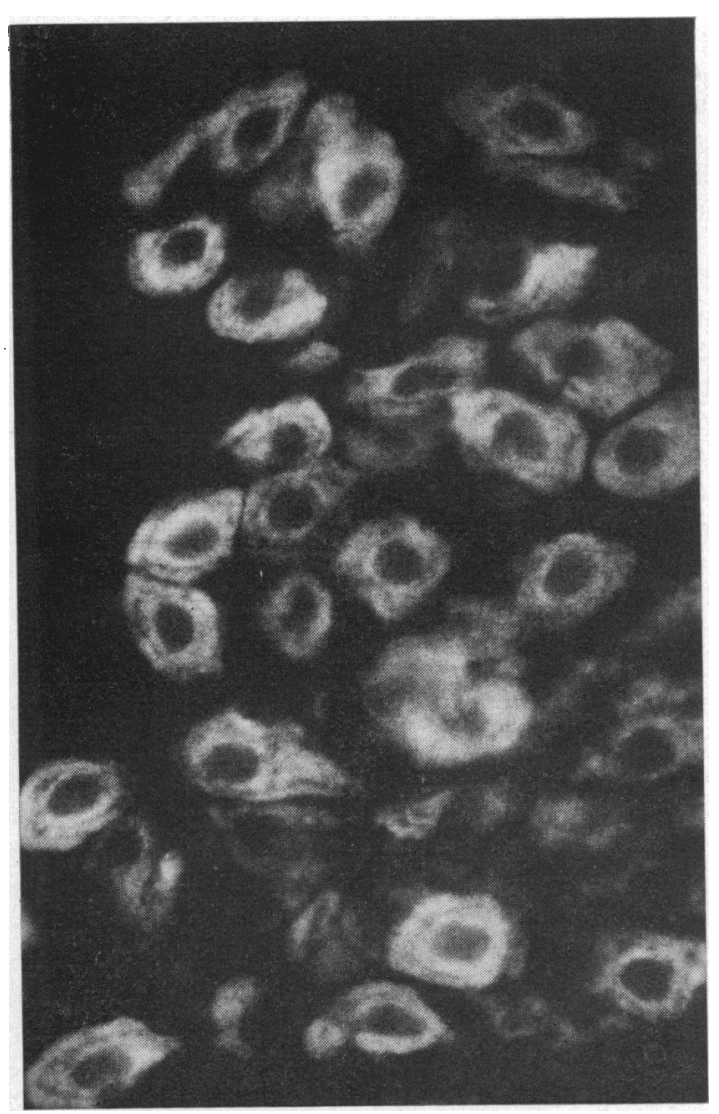

Fig 6 Guinea-pig gastric mucosa stained with the cell membrane antiserum which had been absorbed with antrum and twice with gastric microsomes.

mucosa of other species to a lesser degree than did the pernicious anaemia sera (table I).The human sera reacted strongly with the parietal cells of guinea pig, rabbit, rat, mouse, and frog. The rabbit antisera to the isolated parietal cells gave a strong reaction only on guinea pig stomach sections. Gastric tissue of other species reacted weakly with these antisera.

The antiserum to the parietal-cell membranes, in addition to the cytoplasmic antibody, contained an antibody to the plasma membrane and nuclear membrane. The fluorescing membranes were seen clearly using antiserum absorbed with antrum and hog stomach microsomes (fig 6). This fluorescence could not be abolished by repeated absorption with stomach microsomes, but it was completely eliminated by absorbing the antiserum with the 15000 $\times g$ fraction from guinea-pig stomach. The antiserum was negative in both tests for antibody to IF (see below), and the membrane fluorescence was not removed by absorption with human or guinea-pig gastric juice; therefore it was not an antibody to intrinsic factor.

To demonstrate a parietal cell cytosol antigen, antiserum was made to soluble protein extracted from the body of the guinea-pig stomach. It was absorbed with antrum and hog microsomes and was tested by immunofluorescence. Faint cytoplasmic fluorescence was seen which could not be removed by further absorption with microsomes. Fluorescence also persisted following absorption with gastric juice, suggesting that the antibody was distinct from antibody to intrinsic factor.

\section{COMPLEMENT-FIXING ANTIBODIES}

Immunofluorescent evidence for a distinct antibody to cell membranes was supported by complement fixation. Microsomes from the hog stomach and the $15000 \times g$ fraction from the body of the guinea-pig stomach were used as antigens in order to detect complement-fixing antibodies to both microsomes and cell membranes. The results are shown in table II. The antisera to the three parietal-cell preparations contained an antibody reacting to hog stomach in a titre of $1 / 32$ to $1 / 64$, a range of titre comparable to that found in the sera of patients with pernicious anaemia. Using the $15000 \times g$ fraction as the 


\begin{tabular}{lll}
\hline Serum & Antigen \\
\cline { 2 - 3 } & $\begin{array}{l}\text { Hog Stomach } \\
\text { Microsomes } \\
(1 \mathrm{mg} / \mathrm{ml})\end{array}$ & $\begin{array}{l}\text { Guinea } \text { Pig } \\
15000 \times \mathrm{g} \text { Pellet } \\
(1 \mathrm{mg} / \mathrm{ml})\end{array}$ \\
\hline $\begin{array}{lll}\text { Antiserum to whole parietal cell } \\
\begin{array}{l}\text { Antiserum to homogenized parietal } \\
\text { cell }\end{array}\end{array}$ & $1 / 64$ & $1 / 32$ \\
$\begin{array}{l}\text { Antiserum to parietal cell } \\
\text { membrane }\end{array}$ & $1 / 32$ & $1 / 64$ \\
$\begin{array}{l}\text { Pernicious anaemia serum } \\
\text { Normal human serum }\end{array}$ & $1 / 32$ & $1 / 256$ \\
Normal rabbit serum & $1 / 32$ & $1 / 4$ \\
\hline
\end{tabular}

Table II Titre of complement-fixing antibodies to gastric antigens

antigen, the antiserum to cell membranes had an antibody titre of $1 / 256$, whereas the other two antisera had much lower titres and pernicious anaemia serum had a titre of only $1 / 4$.

\section{ANTIBODY TO VITAMIN B12 BINDING \\ PROTEINS}

Antibodies that inhibited binding of vitamin $\mathrm{B}_{12}$ by guinea-pig gastric juice were detected using the charcoal assay in antisera to whole parietal cells, parietal-cell homogenate, and in antiserum from one of the two rabbits inoculated with parietal cell membranes. Some antisera to whole cells and parietal-cell homogenate, although not all, inhibited from 20 to $50 \%$ of the binding of $\mathrm{B}_{12}$ by guinea-pig gastric juice. Normal rabbit sera did not inhibit $\mathbf{B}_{12}$ uptake. The guinea-pig mucosal homogenate assay showed that intrinsic-factor-binding antibodies or blocking antibodies or both were present in these antisera. Their titre, however, was quite low compared with that found in pernicious anaemia sera. It can be assumed that the antibody was specific for IF, since the guinea-pig mucosa assay measures uptake of the IF- $\mathrm{B}_{12}$ complex by the mucosa, as opposed to the charcoal assay, in which uptake of $B_{12}$ by non-IF binders occurs. No IF antibody activity was found in the antiserum to parietal cell membranes using either the charcoal or the mucosal homogenate assay.

\section{IMMUNOELECTROPHORESIS AND} IMMUNODIFFUSION

A fourth antibody was detected using immunoelectrophoresis and immunodiffusion. The antiserum from rabbits immunized with homogenized parietal cells was found to contain an antibody against the soluble protein from the body of the guinea-pig stomach. This antibody was not present in the other two antisera. It reacted only with the soluble protein from the body of the stomach; no precipitin arc was obtained with soluble protein from the

\begin{tabular}{lccc}
\hline & \multicolumn{2}{c}{ Mucosa } & Isolated Cells \\
\hline Carbonic anhydrase & 1 & $11 \cdot 6$ & $22 \cdot 93$ \\
\multirow{3}{*}{ Pepsin } & 2 & $12 \cdot 6$ & $31 \cdot 2$ \\
& 1 & 282 & 100 \\
& 2 & 556 & 136 \\
\hline
\end{tabular}

Table III Activity of carbonic anhydrase and pepsin in isolated parietal cells compared with the activities in the mucosa from which the cells were isolated ${ }^{1}$

${ }^{1}$ Enzyme activities are expressed as units/mg protein and the values given are the mean of duplicate estimations for two preparations of parietal cells and the mucosa from which they were isolated.

antrum by immunoelectrophoresis or immunodiffusion. A very weak reaction occurred when soluble protein from isolated parietal cells was used as antigen. The precipitin arc obtained was similar to that using soluble protein from the body of the stomach. These results support the immunofluorescent findings, suggesting the existence of a specific antigen in the parietal cell cytosol.

No antibody against soluble protein could be found in the sera from 30 patients with pernicious anaemia, nor in serum from three patients with chronic atrophic gastritis without the lesion of pernicious anaemia. Canalicular antibody was present in 22 of these. They were tested by immunodiffusion against soluble protein from both the body and the antrum of the guinea-pig stomach. No precipitin arcs were seen.

\section{Discussion}

Isolated liver cells have been successfully obtained by perfusing the liver of rats with collagenase. These isolated cells have been shown to be biochemically active and have been grown in tissue culture for short periods of time. An attempt to adapt this method for the isolation of parietal cells from the guinea-pig stomach has proved unsuccessful in so far as the isolated parietal cells were heavily contaminated with debris and other types of cell. Furthermore, the majority of parietal cells obtained by this method failed to exclude trypan blue. However, preparations of parietal cells with greater than $75 \%$ purity could be obtained by incubating gastric fragments with collagenase in vitro. Once the conditions for isolation had been determined, the method was simple and usually reliable, although unsuccessful procedures occurred occasionally. The greatest difficulty was caused by the presence of large amounts of mucus which trapped the cells in the glands so that they were digested before being released into the surrounding medium. This problem was minimized by using an excess of medium in relation to the mass of gastric tissue. Using the 
methods described by Walder and Lundseth (1963) and by McDougal and deCosse (1970) for the isolation of rabbit parietal cells, we did not obtain satisfactory preparations and, in our hands, we found the method described gave much better and more reliable results. Likewise, we found that the use of pronase failed to isolate healthy parietal cells although this enzyme had been used successfully for isolating the parietal cells from the stomachs of rabbits, mice and Necturus (Blum, Shah, Wiebelhaus, Brennan, Helander, Ceballos, and Sachs, 1971; Romrell, Coppe, and Ito, 1973).

\section{VIABILITY}

Parietal cells appear to be more resistant to enzymatic activity than other gastric mucosal cells, which may largely explain the success of the separative procedure. It was disappointing to find, however, that most cells remained viable for only about an hour, even under optimal conditions. The reasons for this are unknown but may partly be accounted for by damage inflicted by collagenase during the isolation procedure. However, enzymatic methods of separation employed by others do not appear to affect the respiratory rate, the maintenance of transmembrane potentials, and the selective movement of chloride ions against an electrical and concentration gradient by isolated parietal cells. Walder and Lunseth (1963) found a reduction in succinic dehydrogenase activity in their isolated parietal cells whereas in our studies these cells had undiminished activity at 21 hours when they were maintained at $4^{\circ} \mathrm{C}$.

\section{ANTIGEN STUDIES}

These relatively crude separative techniques have provided the means for characterization of four distinct parietal-cell antigens, namely, a membrane component, a microsomal fraction of the cell cytoplasm, a cytosol protein, and Castle's intrinsic factor. None of these antisera contained antibody only to a single antigen, presumably because the antigen preparation was not pure. However, the use of partially purified antigens allowed successful absorption of the resulting antisera so that antibody was seen to react at single well defined sites. This contrasted with our previous experience using differential absorption of antisera to whole gastric mucosal homogenates with mucosal fractions.

Our approach is essentially different from that of Ward and Nairn (1972) who used homogenized whole gastric mucosa of various species and proceeded to physical and chemical fractionating procedures so that all cell types may have contributed antigens. Since only the parietal cell in chronic atrophic gastritis of pernicious anaemia appears to contain the antigens against which an autoimmune response occurs, it seemed to us that, with a view to utilizing specific antigens in subsequent tests of humoral and cellular immune response, it might be desirable to exclude other cell types before proceeding to antigen purification.

This is a preliminary report and so far few conclusions are justified. However, one interesting observation must be recorded. All four rabbit antisera to guinea-pig parietal cells reacted with all the species tested, including Rana catesbiana, though the degree of fluorescence was strikingly brighter with guinea-pig mucosa than any other of the species tested, suggesting some degree of species specificity. Human pernicious anaemia sera do not display these differences, except that, in our laboratory, only 12 out of 17 pernicious anaemia sera positive on human stomach gave positive reactions with gastric mucosa of $R$. catesbiana. This suggests the possibility that more than one antigen-antibody system may be involved. Preliminary studies of absorption with human, hog and frog gastric microsomal preparations suggest that both pernicious anaemia sera and rabbit antisera to guinea-pig parietal cells may sometimes contain a heterologous antibody to frog parietal cell cytoplasm. So far, this antibody has not been found in normal human and rabbit sera. The antibody may be similar to that described by Muller, McGiven and Nairn (1971) and further studies are in progress.

This work was supported by NIH grant AM 06971, and by the US Veterans' Administration. We are grateful to Dr Eve Reaven and Miss Fredericka Boost for the electron microscopy studies. One of us (DPJ) was in receipt of the Radcliffe Travelling Fellowship.

References

Anson, M. L. (1938). The estimation of pepsin, trypsin, papain and cathepsin with hemoglobin. J. gen. Physiol., 22, 79-89.

Ashworth, L. A. E., England, J. M., Fisher, J. M., and Taylor, K. B. (1967). A new method for detection and measurement of intrinsic-factor antibodies. Lancet, 2, 1160-1164.

Baur, S., Roitt, I. M., and Doniach, D. (1965). Characterization of human gastric parietal cell auto-antigen. Immunology, 8, 62-68.

Berry, M. N., and Friend, D. S. (1969). High-yield preparation of isolated rat liver parenchymal cells. J. Cell Biol., 43, 506-520.

Blum, A. L., Shah, G. T., Wiebelhaus, V. D., Brennan, F. T., Helander, H. F., Ceballos, R., and Sachs, G. (1971). Pronase method for isolation of viable cells from Necturus gastric mucosa. Gastroenterology, 61, 189-200.

Bradford, N. M., and Davies, R. E. (1950). The site of hydrochloric acid production in the stomach determined by indicators. Biochem. J., 46, 414-420.

BreMiller, R. A. (1961). Attempt to separate cells of the gastric mucosa. Gastroenterology, 40, 798-802.

Chanarin, I., and James, D. (1974). Humoral and cell-mediated intrinsic-factor antibody in pernicious anaemia. Lancet, 1, 1078-1080. 
Donnelley, M. (1951). Studies in experimental immunology of influenza VII. An improved complement-fixation technique. Aust. $J$. exp. Biol. med. Sci., 29, 137-146.

Fisher, J. M., and Taylor, K. B. (1965). A comparison of autoimmune phenomena in pernicious anaemia and chronic atrophic g astritis. New Engl. J. Med., 272, 499-503.

Fisher, J. M., and Taylor, K. B. (1969). The intracellular localization of Castle's intrinsic factor by an immunofluorescent technique using autoantibodies. Immunology, 16, 779-784.

Goldstone, A. H., Calder, E. A., Barnes, E. W., and Irvine, W. J. (1973). The effect of gastric antigens on the in vitro migration of leucocytes from patients with atrophic gastritis and pernicious anaemia. Clin. exp. Immunol., 14, 501-508.

Gottlieb, C. K., Lau, S., Wasserman, L. R., and Herbert, V. (1965) Rapid charcoal assay for intrinsic factor (IF), gastric juice unsaturated $\mathrm{B}_{12}$ binding properties. Clin. exp. Immunol., 10, 435-457.

Hausamen, T. U., Brus, I., Fisher, J. M., and Taylor, K. B. (1969a). Inhibition of production of gastric acid by gastric antibodies. (Abstr.). Clin. Res., 17, 594.

Hausamen, T. U., Halcrow, D. A., and Taylor, K. B. (1969b). Biological effects of gastrointestinal antibodies. II. Histological changes in the stomach induced by injection of specific heterologous antibodies. Gastroenterology, 56, 1062-1070.

Hoedemaeker, P. J., and Ito, S. (1970). Ultrastructural localization of gastric parietal cell antigen with peroxidase-coupled antibody. Lab. Invest., 22, 184-188.

Inada, M., and Glass, G. B. J. (1972). Effects of prolonged administration of intrinsic factor antibodies on gastric morphology and secretion in rats. (Abstr.) Fed. Proc., 31, 299.
Karler, R., and Woodbury, D. M. (1963). Modified manometric method for determination of carbonic anhydrate in tissues. Ann. Biochem., 6, 381-392.

Lowry, O. H., Rosebrough, N. J., Farr, A. L., and Randall, R. J. (1951). Protein measurement with folin phenol reagent. J. biol. Chem., 193, 265-275.

McDougal, W. S , and DeCosse, J. J. (1970). Method for determining differential secretory function of isolated cells in vitro: chloride movement in isolated parietal cells. Exp. cell. Res., 61, 203-206.

Muller, H. K., McGiven, A. R., and Nairn, R. C. (1971). Immunofluorescent staining of rat parietal cells by human antibody unrelated to pernicious anaemia. J. clin. Path., 24, 13-14.

Nachlas, M. M., Tsou, K. C., de Souza, E., Cheng, C. S., and Seligman, A. M. (1957). Cytochemical demonstration of succinic dehydrogenase by the use of a new p-nitrophenyl substituted ditetrazole. J. Histochem. Cytochem., 5, 420-436.

Romrell, L. J., Coppe, M. R., and Ito, S. (1973). The isolation of viable, highly enriched fractions of mouse parietal cells by velocity sedimentation. Anat. Rec., 175, 427.

Tanaka, N., and Glass, G. B. J. (1970). Effects of prolonged administration of parietal cell antibodies from patients with atrophic gastritis and pernicious anemia on the parietal cell mass and hydrochloric acid output in rats. Gastroenterology, 58, 482-494.

Walder, Arnold, I., and Lunseth, John B. (1963). A technic for separation of the cells of the gastric mucosa. Proc. Soc. exp. Biol. (N.Y.), 112, 494-496.

Ward, H. A., and Nairn, R. C. (1972). Gastric parietal cell autoantigen: physical chemical and biological properties. Clin. exp. Immunol., 10, 435-457. 